ISSN 1420-3049

http://www.mdpi.org

\title{
Epoxidation of Diosgenin, 25(R)-1,4,6-Spirostatrien-3-one and
}

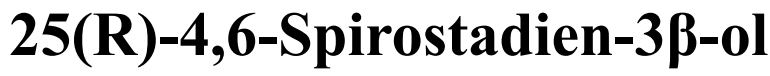

\section{Eunsook Ma* and Jongwon Kim}

College of Pharmacy, Catholic University of Daegu, Hayang, 712-702, Korea, Tel. 82-053-850-3621, Fax. 82-053-850-3602.

* Author to whom correspondence should be addressed; E-mail: masook@,cataegu.ac.kr

Received: 18 September 2003; in revised form: 12 December 2003 / Accepted: 18 December 2003 / Published: 31 December 2003

\begin{abstract}
Upon treatment of 25(R)-spirost-5-en-3 $\beta$-ol (diosgenin), 25(R)-1,4,6spirostatrien-3-one and 25(R)-4,6-spirostadien-3 $\beta$-ol with $30 \% \mathrm{H}_{2} \mathrm{O}_{2}$ and $5 \% \mathrm{NaOH}$ in methanol, diosgenin did not react, 25(R)-1,4,6-spirostatrien-3-one was converted to $25(\mathrm{R})-1 \alpha, 2 \alpha$-epoxy-4,6-spirostadien-3-one and 25(R)-4,6-spirostadien-3 $\beta$-ol was oxidized to give a small amount of 25(R)-4,6-spirostadien-3-one, while most of the original starting material remained unchanged. On the other hand, reactions of diosgenin, 25(R)-1,4,6-spirostatrien-3-one and 25(R)-4,6-spirostadien-3 $\beta$-ol with $m$-chloroperoxy-

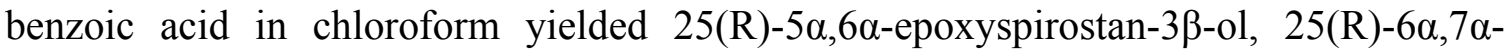
epoxy-1,4-spirostadien-3-one and 25(R)-4 $\beta, 5 \beta$-epoxy-6-spirosten-3 $\beta$-ol, respectively.
\end{abstract}

Keywords: Diosgenin, Stereoselective epoxidation, $\mathrm{H}_{2} \mathrm{O}_{2}$, m-Chloroperoxybenzoic acid 


\section{Introduction}

Diosgenin (25(R)-spirost-5-en-3 $\beta$-ol) is the steroidal saponin which is isolated from the Mexican yam (Dioscorea). Estrogenic, progesterogenic and anti-inflammatory effects have been hypothesized for diosgenin due to its structural similarity to estrogen and progesterone precursors [1]. Diosgenin has been reported to lower serum cholesterol in chicken and rabbits fed cholesterol and to decrease liver cholesterol in cholesterol-fed rats, an action associated with increased rates of cholesterol synthesis, increased secretion of cholesterol into bile acid, and increased fecal excretion of neutral sterols [2-6].

Diosgenin was used commercially to produce steroid hormones such as cortisone, estrogen, and progesterone by in vitro chemical modification [7]. 1 $\alpha$-Hydroxydiosgenin and $1 \beta$-hydroxydiosgenin (ruscogenin) were used as starting materials in the synthesis of $1 \alpha$-hydroxycholesterol and $1 \beta$-hydroxycholesterol by chemical removal of its side chain $[8,9]$. The study showed that $1 \beta$-hydroxydiosgenin could be used as a potential starting material for $1 \alpha$ - or $1 \beta$-hydroxy vitamin $\mathrm{D}$ analogs $[10,11]$. Diosgenin was also used as the natural source to synthesize dehydroepiandrosterone (DHEA), a steroid that declines with age, but has significant activities as an antioxidant to modify serum lipid levels and which inhibits proliferation of cancer and noncancer cells in both in vitro and in vivo studies [12-14].

Since $1 \alpha$ - or $1 \beta$-hydroxydiosgenin is of great interest as a starting material in the synthesis of various active compounds, it is desirable to make hydroxydiosgenin derivatives more available for biological experimentation. The efficient stereoselective synthesis of hydroxydiosgenin derivatives requires a stereoselective epoxidation of double bond as an important intermediate step. Consequently we have examined position selective and reagent selective epoxidations of the olefinic position of diosgenin, 25(R)-1,4,6-spirostatrien-3-one [9] and 25(R)-4,6-spirostadien-3 $\beta$-ol using $30 \% \mathrm{H}_{2} \mathrm{O}_{2}$ and $m$-chloroperoxybenzoic acid as epoxidizing agents, respectively.

\section{Results and discussion}

In this paper, we report the results of a study of the reagent selective and regioselective epoxidation reactions of diosgenin derivatives. The syntheses were accomplished by the procedures described in Scheme 1. 25(R)-Spirost-5-en-3 $\beta$-ol (diosgenin) was epoxidized with $30 \% \mathrm{H}_{2} \mathrm{O}_{2}$ and $5 \%$ $\mathrm{NaOH}$ in methanol, but it did not react, whereas when diosgenin was treated with $m$-chloroperoxybenzoic acid ( $m \mathrm{CPBA}$ ) in $\mathrm{CHCl}_{3}$ it gave 25(R)-5 $\alpha, 6 \alpha$-epoxy-spirostan-3 $\beta$-ol (1). In this case, the equatorial attack of the $m \mathrm{CPBA}$ to the double bond of diosgenin is destabilized by the steric interaction between the reagent and the axial $\mathrm{CH}_{3}$ group (number 19), therefore the downside axial attack is preferred for reagent approach in the transition state. The oxidative dehydrogenation of diosgenin with 2,3-dichloro-5,6-dicyano-1,4-benzoquinone in refluxing 1,4-dioxane gave 25(R)- 
1,4,6-spirostatrien-3-one (2). Only the 1,2-double bond of compound 2 was selectively epoxidized with $30 \% \mathrm{H}_{2} \mathrm{O}_{2}$ and $5 \% \mathrm{NaOH}$ in methanol to yield $25(\mathrm{R})-1 \alpha, 2 \alpha$-epoxy-4,6-spirostadien-3-one (3) $[9,15]$. In the absence of directing effects, electrophilic epoxidation of the double bond takes place predominantly from the $\alpha$-face of the molecule.

\section{Scheme 1}
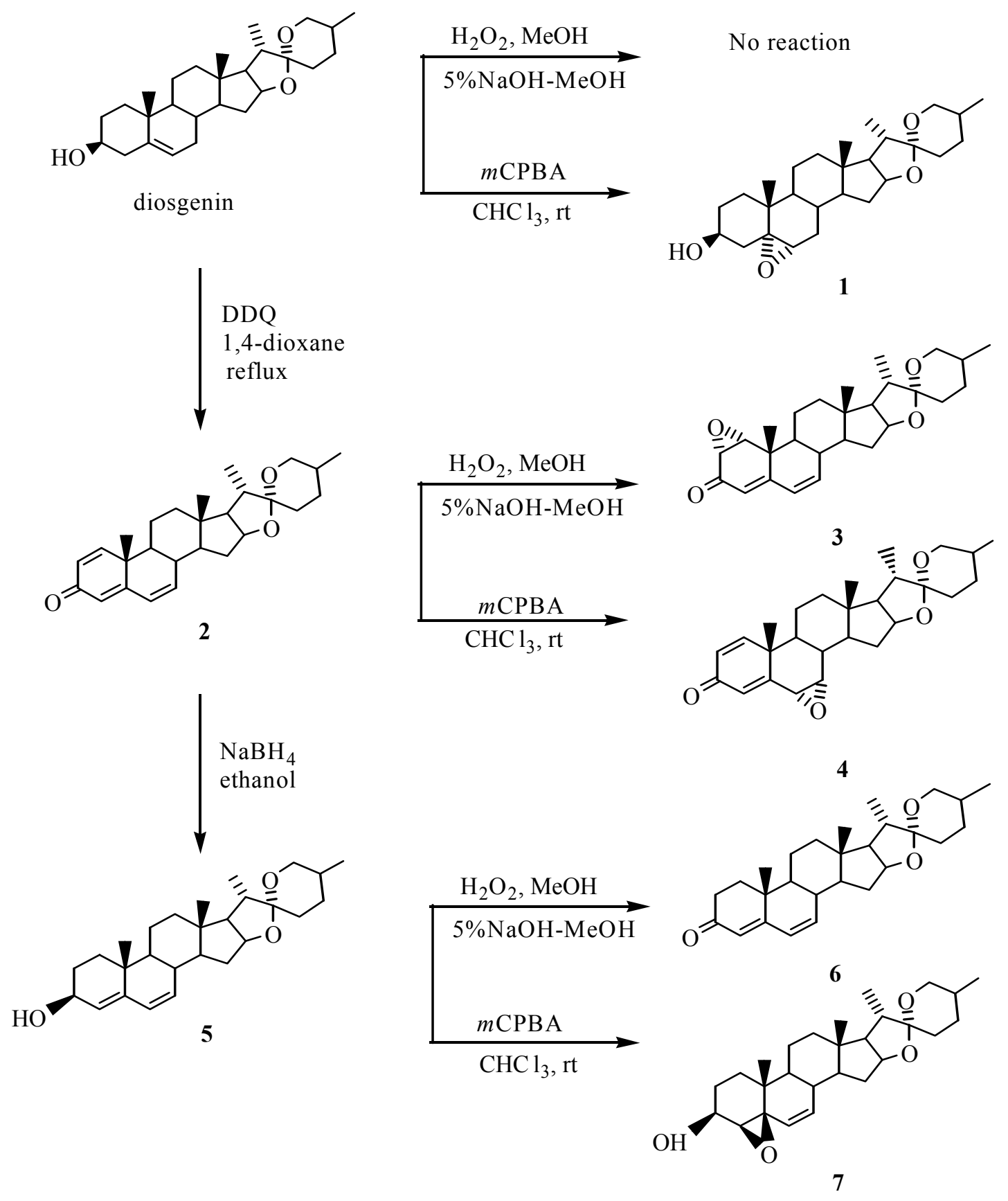
On the other hand, when compound 2 was epoxidized with $m \mathrm{CPBA}, 25(\mathrm{R})-6 \alpha, 7 \alpha$-epoxy-1,4spirostadien-3-one (4) was obtained. This result is basically caused by the attack of the $m \mathrm{CPBA}$ directed on the less hindered $\alpha$-face of 6,7-double bond. 25(R)-1,4,6-Spirostatrien-3-one (2) was

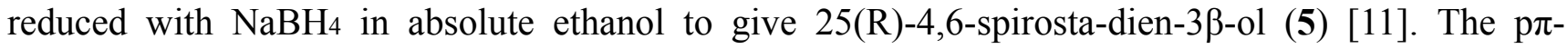
electronic system of compound 5 is more stable than 25(R)-1,4- spirostadien-3 $\beta$-ol [16]. When compound 5 was epoxidized with $30 \% \mathrm{H}_{2} \mathrm{O}_{2}$ and $5 \% \mathrm{NaOH}$ in methanol, the 3-hydroxy group was dehydrogenated to yield only $25 \%$ of $25(\mathrm{R})-4,6$-spirostdien-3-one (6) while most of the original starting material was recovered. In the case of $\mathrm{H}_{2} \mathrm{O}_{2}$, epoxidation seems to only occur in the presence of a carbonyl group conjugated with the double bond. Compound $\mathbf{5}$ was epoxidized with $m \mathrm{CPBA}$ to form $25(\mathrm{R})-4 \beta, 5 \beta$-epoxy-6-spirosten-3 $\beta$-ol (7). In this case the presence of the $3 \beta$-hydroxy group of the allylic alcohol directed the epoxidation exclusively to the $\beta$-face of the double bond of the molecule [16,17]. All synthesized compounds were identified by IR, ${ }^{1} \mathrm{H}-\mathrm{NMR},{ }^{13} \mathrm{C}-\mathrm{NMR}$ and mass spectra, respectively.

\section{Acknowledgements}

The authors wish to thank the Catholic University of Daegu for financial support.

\section{Experimental}

\section{General}

Reactions were performed under nitrogen. Solvents were purified and dried prior to use. Melting points were measured on Thomas-Hoover melting point apparatus in open capillary tubes and are not corrected. ${ }^{1} \mathrm{H}$ - and ${ }^{13} \mathrm{C}$-NMR spectra were obtained on Gemini $200 \mathrm{MHz}$ or $50 \mathrm{MHz}$ spectrometers in $\mathrm{CDCl}_{3}$, chemical shifts $\delta$ are in ppm are relative to tetramethylsilane, coupling constants $J$ in $\mathrm{Hz}$. IR spectra were determined for $\mathrm{KBr}$ pellets on a Jasco FT-IR 300E spectrometer. FAB mass spectra were recorded on a Tandem mass spectrometer. Analytical TLC was performed on Merck precoated silica gel $60 \mathrm{~F}_{254}$ plates. Column chromatography was carried out on Merck silica gel 9385 (230-400 mesh).

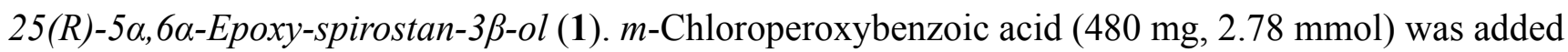
at room temperature to a solution of $25(\mathrm{R})$-spirost-5-en-3 $\beta$-ol (diosgenin, $1 \mathrm{~g}, 2.4 \mathrm{mmol}$ ) in $\mathrm{CHCl}_{3}$ $(100 \mathrm{~mL})$. The mixture was stirred under nitrogen at room temperature for 18 hours. Water was added and the aqueous layer was extracted with several portions of $\mathrm{CHCl}_{3}$ and the organic extracts were combined, dried with $\mathrm{MgSO}_{4}$, filtered and evaporated to leave a crude solid that was recrystallized from ethyl acetate and $n$-hexane (1:5) to afford 1 as white crystals. Yield: $960 \mathrm{mg}$ (93\%); mp : 202.3-

204.5 ${ }^{\circ}$; IR $\left(\mathrm{cm}^{-1}\right): 3513,3401 ;{ }^{1} \mathrm{H}-\mathrm{NMR} \delta: 0.71(3 \mathrm{H}, \mathrm{s}, \mathrm{H}-27), 0.78(3 \mathrm{H}, \mathrm{s}, \mathrm{H}-18), 0.94(3 \mathrm{H}, \mathrm{d}$, 
$J=6.8 \mathrm{~Hz}, \mathrm{H}-21), 1.07$ (3H, s, H-19), $2.90(1 \mathrm{H}, \mathrm{d}, J=14.0 \mathrm{~Hz}, \mathrm{H}-6), 3.30-3.52$ (2H, m, H-26), 3.87-3.96 $(1 \mathrm{H}, \mathrm{m}, \mathrm{H}-3), 4.35-4.44$ (1H, m, H-16); ${ }^{13} \mathrm{C}-\mathrm{NMR} \delta: 109.3,80.7,68.7,66.9,65.7,61.9,59.2,56.7$, 42.6, 41.7, 40.4, 39.9, 39.5, 35.1, 31.2, 30.4, 29.6, 29.1, 28.9, 20.6, 17.2, 16.4, 16.1,14.6; FABMS $(\mathrm{M}+\mathrm{H})^{+}: 431.2$.

25(R)-1,4,6-Spirostatrien-3-one (2). A solution of diosgenin (5 g, $12 \mathrm{mmol}$ ) and 2,3-dichloro-5,6dicyano-1,4-benzoquinone $(10 \mathrm{~g}, 88 \mathrm{mmol})$ in dioxane $(125 \mathrm{~mL})$ was refluxed for 24 hours under nitrogen. The reaction mixture was cooled down and the resulting precipitate was filtered off and washed with dichloromethane. The filtrate was rotary evaporated to dryness and the dark brown residue was purified by column chromatography on silica gel (ethyl acetate/ $n$-hexane $=1: 7$ ) to afford white crystals of 2 . Yield: $3.04 \mathrm{~g}(62 \%)$; mp: 207.1-209.2 ${ }^{\circ} \mathrm{C}$; IR $\left(\mathrm{cm}^{-1}\right): 1661,1452 ;{ }^{1} \mathrm{H}-\mathrm{NMR} \delta: 0.80$ (3H, d, J=3.1Hz, H-27), 0.90 (3H, s, H-18), 1.00 (3H, d, J=3.4Hz, H-21), 1.21 (3H, s, H-19), 3.363.51 (2H, m, H-26), 4.38-4.49 (1H, m, H-16), 6.00 (2H, d, J=9.4Hz, H-6, H-7), 6.23 (2H, dd, J=2.0, $12.0 \mathrm{~Hz}, \mathrm{H}-2, \mathrm{H}-4), 7.05$ (1H, d, $J=10.0 \mathrm{~Hz}, \mathrm{H}-1) ;{ }^{13} \mathrm{C}-\mathrm{NMR} \delta: 162.5$ 152.9, 138.1, 128.3, 127.7, 123.9, $109.3,80.5,67.0,62.0,53.4,48.5,41.7,41.1,39.5,37.8,31.4,31.3,30.3,29.8,28.8,21.8,20.9,17.2$, 16.4, 14.5; FABMS $(\mathrm{M}+\mathrm{H})^{+}: 409.2$.

25(R)-1 $\alpha, 2 \alpha$-Epoxy-4,6-spirostadien-3-one (3). A mixture of $5 \% \mathrm{NaOH}-\mathrm{MeOH}(0.6 \mathrm{~mL})$ and $30 \%$ $\mathrm{H}_{2} \mathrm{O}_{2}(6 \mathrm{~mL})$ was added to a solution of the trienone $2(3 \mathrm{~g}, 7.34 \mathrm{mmol})$ in methanol $(60 \mathrm{~mL})$. The mixture was stirred at room temperature for 22 hours, at which time TLC indicated reaction completion, then extracted with dichloromethane. The organic layers were combined and washed with brine and $\mathrm{H}_{2} \mathrm{O}$, dried over $\mathrm{MgSO}_{4}$, filtered, and concentrated to leave a crude solid. Column chromatography on silica gel, eluting with ethyl acetate/ $n$-hexane (1:5), gave pure white crystals of epoxide 3. Yield: $2.53 \mathrm{~g}(81 \%)$; mp: $219.2-220.8^{\circ} \mathrm{C}$; IR $\left(\mathrm{cm}^{-1}\right): 1669,1459 ;{ }^{1} \mathrm{H}-\mathrm{NMR} \delta: 0.73(3 \mathrm{H}, \mathrm{d}$, $J=6.2 \mathrm{~Hz}, \mathrm{H}-27), 0.88$ (3H, s, H-18), 0.92 (3H, d, $J=6.6 \mathrm{~Hz}, \mathrm{H}-21), 1.13$ (3H, s, H-19), 3.27 (1H, br d, $J=10.8 \mathrm{~Hz}, \mathrm{H}-26), 3.35-3.46$ (2H, m, H-26, H-2), 3.51 (1H, d, $J=4.2 \mathrm{~Hz}, \mathrm{H}-1), 4.43-4.46$ (1H, m, H-16), $5.58(1 \mathrm{H}, \mathrm{d}, J=1.4, \mathrm{H}-4), 6.01$ (2H, m, H-6, H-7); ${ }^{13} \mathrm{C}-\mathrm{NMR} \delta: 193.6,157.5,138.8,126.9,118.6$, $108.3,79.3,65.9,58.4,53.7,52.0,45.1,40.7,40.0,38.2,37.0,36.1,30.3,30.2,29.2,27.8,20.0,17.5$, 16.1, 15.1, 13.4; FABMS $(\mathrm{M}+\mathrm{H})^{+}: 425.2$.

25(R)-6 $\alpha, 7 \alpha$-epoxy-1,4-spirostadien-3-one (4). mCPBA (490 $\mathrm{mg}, 2.84 \mathrm{mmol}$ ) was added to a solution of trienone $2(1 \mathrm{~g}, 2.45 \mathrm{mmol})$ in $\mathrm{CHCl}_{3}(100 \mathrm{~mL})$ at room temperature. The reaction mixture was stirred at the same temperature until no starting material could be detected by TLC. The mixture was stirred with $\mathrm{H}_{2} \mathrm{O}$ and then extracted with dichloromethane. The extract was dried over $\mathrm{MgSO}_{4}$, filtered, and evaporated to give a pale yellow precipitate. Column chromatography on silica gel, eluting with ethyl acetate/ $n$-hexane (1:5) gave the pure white crystals of epoxide 4. Yield: $655 \mathrm{mg}$ (63\%); mp: 264-265.5 ${ }^{\circ}$; IR $\left(\mathrm{cm}^{-1}\right)$ : 1653, 1448; ${ }^{1} \mathrm{H}-\mathrm{NMR} \delta: 0.79$ (3H, d, J=6.2Hz, H-27), 0.88 (3H, s, H-18), 
$0.98(3 \mathrm{H}, \mathrm{d}, J=6.6 \mathrm{~Hz}, \mathrm{H}-21), 1.21(3 \mathrm{H}, \mathrm{s}, \mathrm{H}-19), 3.31-3.50(2 \mathrm{H}, \mathrm{m}, \mathrm{H}-26, \mathrm{H}-7), 3.64$ (1H, d, $J=3.6 \mathrm{~Hz}$, H-6), 4.50-4.67 (1H, m, H-16), 6.24 (1H, dd, $J=1.6,10.2 \mathrm{~Hz}, \mathrm{H}-2), 6.48$ (1H, d, J=1.8Hz, H-4), 7.0 $(1 \mathrm{H}, \mathrm{d}, J=16.4 \mathrm{~Hz}, \mathrm{H}-1) ;{ }^{13} \mathrm{C}-\mathrm{NMR} \delta: 185.2,159.7,153.2,131.2,127.8,101.4,80.7,67.6,61.9,53.9$, 51.8, 50.9, 41.8, 41.2, 41.1, 39.3, 38.4, 35.1, 31.5, 31.3, 30.3, 28.9, 22.0, 20.9, 17.2, 16.3, 14.6; FABMS $(\mathrm{M}+\mathrm{H})^{+}: 425.2$.

25(R)-4,6-Spirostadien-3 $\beta$-ol (5). To a solution of compound 2 (1 g, $2.45 \mathrm{mmol})$ in absolute ethanol $(100 \mathrm{~mL}), \mathrm{NaBH}_{4}(370 \mathrm{mg}, 9.8 \mathrm{mmol})$ was added portionwise at room temperature. The resulting mixture was stirred overnight at this temperature, then concentrated by rotary evaporation to afford a white solid. This was stirred with water for 30 minutes, then extracted with dichloromethane. The organic layer was washed with water and dried with $\mathrm{MgSO}_{4}$, filtered, and concentrated to give a white solid, which was recrystallized from ethyl acetate and $n$-hexane to afford white crystals. Yield: 900 mg (89 \%); mp: $184-186{ }^{\circ} \mathrm{C}$; IR $\left(\mathrm{cm}^{-1}\right)$ : 3418, 2929; ${ }^{1} \mathrm{H}-\mathrm{NMR} \delta: 0.77$ (3H, d, $\left.J=2.4 \mathrm{~Hz}, \mathrm{H}-27\right), 0.81$ (3H, s, H-18), 0.97 (3H, d, J=6.8Hz, H-21), 1.01 (3H, s, H-19), 3.34 (1H, br d, J=9.0Hz, H-26), 3.373.52 (1H, m, H-26), 4.23-4.31 (1H, m, H-3), 4.36-4.37 (1H, m, H-16), 5.37 (1H, br s, H-6), 5.62 (1H, br d, $J=10.0 \mathrm{~Hz}, \mathrm{H}-4), 5.92$ (1H, dd, $J=2.8,9.8 \mathrm{~Hz}, \mathrm{H}-7) ;{ }^{13} \mathrm{C}-\mathrm{NMR} \delta: 144.7,131.0,128.2,126.4,109.3$, 80.8, 68.1, 67.0, 62.2, 54.0, 51.6, 41.7, 41.5, 40.0, 37.1, 35.3, 33.7, 31.5, 30.4, 29.2, 28.9, 20.7, 18.3, 17.2, 16.5, 14.6; FABMS $(\mathrm{M}+\mathrm{H})^{+}: 413.2$.

25(R)-4,6-Spirostadien-3-one (6). To a solution of compound 5 (500 $\mathrm{mg}, 1.2 \mathrm{mmol})$ in methanol (10 $\mathrm{mL})$ was added a mixture of $5 \% \mathrm{NaOH}-\mathrm{MeOH}(0.25 \mathrm{~mL})$ and $30 \% \mathrm{H}_{2} \mathrm{O}_{2}(0.75 \mathrm{~mL})$ and then it was treated as described for the synthesis of compound 3. Pure compound $\mathbf{6}$ was obtained as white crystals by column chromatography (ethyl acetate- $n$-hexane=1:5). Yield: $123 \mathrm{mg}(25 \%)$;p: $108-110^{\circ} \mathrm{C}$; IR $\left(\mathrm{cm}^{-1}\right)$ : 2940, $1664 ;{ }^{1} \mathrm{H}-\mathrm{NMR} \delta: 0.80(3 \mathrm{H}, \mathrm{d}, J=6.4 \mathrm{~Hz}, \mathrm{H}-27), 0.87$ (3H, s, H-18), 0.98 (3H, d, $J=6.4 \mathrm{~Hz}, \mathrm{H}-21), 1.26$ (3H, s, H-19), 3.37-3.50 (1H, m, H-26), 4.40-4.51 (1H, m, H-16), 5.67 (1H, s, $\mathrm{H}-4), 6.11$ (2H, d, $J=2.4 \mathrm{~Hz}$ H-6, H-7); ${ }^{13} \mathrm{C}-\mathrm{NMR} \delta: 163.4,140.6,127.8,123.6,109.2,80.4,66.8,62.0$, 53.1, 50.7, 41.6, 41.3, 39.5, 37.2, 36.1, 33.9, 33.8, 31.3, 31.2, 30.2, 29.6, 28.7, 20.4, 17.1, 16.3, 16.2, 14.4; FABMS $(\mathrm{M}+\mathrm{H})^{+}: 411.2$.

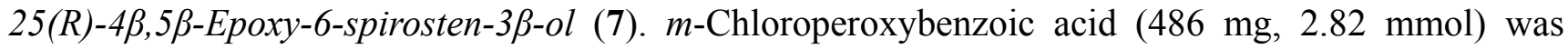
added to a solution of dienol $5(1 \mathrm{~g}, 2.43 \mathrm{mmol})$ in $\mathrm{CHCl}_{3}(100 \mathrm{~mL})$ at room temperature and then the reaction mixture was treated as described for synthesis of compound 1. Pure compound 7 was obtained as white crystals by column chromatography (ethyl acetate- $n$-hexane $=1: 3$ ). Yield: $603 \mathrm{mg}$ (58 \%); mp : 114-116 ${ }^{\circ} \mathrm{C}$; IR $\left(\mathrm{cm}^{-1}\right): 3500,2950 ;{ }^{1} \mathrm{H}-\mathrm{NMR} \delta: 0.74$ (3H, d, J=6.0Hz, H-27), 0.84 (3H, s, $\mathrm{H}-18), 0.96(3 \mathrm{H}, \mathrm{d}, J=6.8 \mathrm{~Hz}, \mathrm{H}-21), 1.28(3 \mathrm{H}, \mathrm{s}, \mathrm{H}-19), 3.23-3.45$ (2H, m, H-26), 3.55-3.65 (1H, m, H-3), 4.15 (1H, d, J=3.4Hz, H-4), 4.60-4.70 (1H, m, H-16), 5.60 (1H, dd, J=2.2, 8.0Hz, H-7), 5.66 $(1 \mathrm{H}, \mathrm{d}, J=2.2 \mathrm{~Hz}, \mathrm{H}-6) ;{ }^{13} \mathrm{C}-\mathrm{NMR} \delta: 149.4,134.6,127.6,125.0,109.4,80.6,71.9,69.3,66.9,61.9$, 
49.3, 44.0, 41.8, 40.3, 39.4, 37.2, 36.6, 35.9, 31.8, 31.4, 30.3, 28.8, 25.2, 20.2, 19.5, 17.2, 16.0, 14.6;

FABMS $(\mathrm{M}+\mathrm{H})^{+}: 429.2$.

\section{References}

1. Dewick, P. M. Medicinal Natural Products, 2nd ed.; John Wiley \& Sons: Chichester, U.K., 2002; pp. 237-289.

2. Laguna, J.; Gomez-Puyoy, A.; Pena, A.; Guzman-Garcia, J. Effect of diosgenin on cholesterol metabolism. J. Atheroscler. Res. 1962, 2, 459-470.

3. Peifer, J. J.; Guzman, J. Hypocholesterolemic effects of diosgenin in the rat. Circulation 1966, 34, III-25.

4. Accatino, L.; Pizarro, M.; Solis, N.; Koenig, C. S. Effects of diosgenin a plant-derived steroid, on bile secretion and hepatocellular cholestasis induced by estrogens in the rat. Hepatology 1998, 28, 129-140.

5. Cayen, M. N.; Dvornik, D. Effect of diosgenin on lipid metabolism in rats. J. Lipid Res. 1979, 20, 162-174.

6. Uchida, K.; Takase, H.; Nomura, Y.; Takeda, K.; Takeuchi, N.; Ishikawa, Y. Changes in biliary and fecal bile acids in mice after treatments with diosgenin and $\beta$-sitosterol. J. Lipid Res. 1984, $25,236-245$.

7. Datt, K.; Datta, S. K.; Datta, P. C. Pharmacognostic evaluation of potential yams Dioscorea. J. Econ.Taxon. Bot. 1984, 5, 181-196.

8. Noam, M.; Tamir, I.; Breuer, E.; Mechoulam, R. Conversion of ruscogenin into $1 \alpha$ - and $1 \beta$ hydroxycholesterol. Tetrahedron 1981, 37, 597-604.

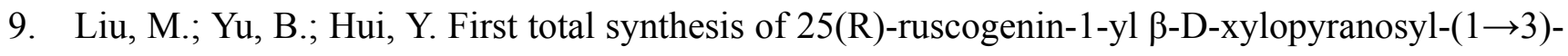
( $\beta$-D-glucopyranosyl- $(1 \rightarrow 2)-\beta$-D-fucopyranoside, an Ophiopogonis saponin from the tuber of Liliope muscari (Decne.). Tetrahedron Lett. 1998, 39, 415-418.

10. Furst, A.; Labler, L.; Meier, W. An effect procedure for preparing $1 \alpha, 3 \beta$-dihydroxy- $\Delta^{5}$-steroids by

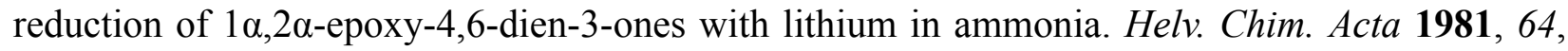
1870-1892.

11. Kobayashi, Y.; Taguchi, T.; Mitsuhashi, S.; Eguchi, T.; Ohshima, E.; Ikekawa, N. Studies on organic fluorine compounds. XXXIX. Studies on steroids. LXXIX. Synthesis of 1 1, 25-dihydroxy26,26,26,27,27,27-hexafluorovitamin D. Chem. Pharm. Bull. 1982, 30, 4297-4303.

12. Araghiniknam, M.; Chung, S.; Tresa, N.-W.; Eskelson, C.; Watson, R. R. Antioxidant activity of dioscorea and dehydroepiandrosterone (DHEA) in older humans. Life Sci. 1996, 59, 147-157

13. Schulz, S.; Klann, R. C.; Schonfeld, S.; Nyce J. W. Mechanisms of cell growth inhibition and cell cycle arrest in human colonic adenocarcinoma cells by dehydroepiandrosterone: role of isoprenoid biosynthesis. Cancer Res. 1992, 52, 1372-1376. 
14. Boros, L. G.; Puigjaner, J.; Cascante, M; Lee, W. N.; Brandes, J. L.; Brassilian, S. Oxythiamine and dehydroepiandrosterone inhibit the nonoxidative synthesis of ribose and tumor cell proliferation. Cancer Res. 1997, 57, 4242-4248.

15. Gao, H.; Dias J. R. Synthetic studies toward 1 $\alpha$-hydroxytestosterone from testosterone. Fourth International Electronic Conference on Synthetic Organic Chemistry (ECSOC-4), 2000, September, 1-30.

16. Gamoh, K.; Hirayama, M.; Ikekawa, N. Stereocontrolled synthesis of Withanolide D and related compounds. J. Chem. Soc., Perkin Trans. I 1984, 440-454.

17. Sharpless, K. B.; Verhoeven, T. R. Metal-catalysed, highly selective oxygenations of olefins and acetylenes with tert-butyl hydroperoxide. Practical considerations and mechanisms. Aldrichim. Acta. 1979, 12, 63-75.

Sample Avalability: Samples of compounds 1, 2, 3, 4, $\mathbf{5}$ and $\mathbf{7}$ are available from the author.

(C) 2003 by MDPI (http://www.mdpi.org). Reproduction is permitted for noncommercial purposes. 